\title{
ОСОБЛИВОСТІ ВИКЛАДАННЯ ДИСЦИПЛІНИ “МЕДИЦИНА КАТАСТРОФ” ДЛЯ СТУДЕНТІВ МЕДИЧНИХ ВНЗ У СУЧАСНИХ УМOBAX
}

\author{
К. В. Вовк, О. В. Сокруто, Є. Я. Ніколенко \\ Харківський національний університет імені В. Н. Каразіна
}

\section{PECULIARITIES OF TEACHING OF THE DISCIPLINE "MEDICINE OF CATASTROPHES" FOR STUDENTS OF MEDICAL HIGHER EDUCATIONAL ESTABLISHMENTS IN MODERN CONDITIONS}

\author{
K. V. Vovk, O. V. Sokruto, Ye. Ya. Nikolenko \\ Kharkiv National University by V. N. Karazin
}

\begin{abstract}
У статті доведена необхідність та доцільність вивчення дисципліни “Медицина катастроф” на додипломному етапі підготовки лікарів та наведений кафедральний досвід викладання цієї дисципліни на медичному факультеті ХНУ імені В. Н. Каразіна.
\end{abstract}

In the article it was proven a necessity and expedience of study of the discipline "Medicine of catastrophes" on the prediploma stage of doctors' training and department experience of teaching of this discipline on a medical faculty of KhNU by V. N. Karazin was presented.

Вступ. Події, які відбуваються у світі, наочно демонструють, що незважаючи на високі темпи росту як економічно розвинутих країн, так і країн, що розвиваються, природні стихійні лиха завдають їм багатомільйонних матеріальних втрат та численних людських жертв. Землетруси, пожежі, цунамі, тайфуни і т. ін. усе частіше нагадують нам про необхідність враховувати можливість їхньої появи. Поряд із природними катастрофами досить часто відбуваються регіональні збройні конфлікти, терористичні акти, в яких отримують поранення та гинуть люди [1].

Для надання безкоштовної медичної допомоги потерпілим від надзвичайних ситуацій $(\mathrm{HC})$ техногенного та природного характеру громадянам, рятівникам та особам, які беруть участь у ліквідації НС, діє Державна служба медицини катастроф (ДСМК) як особливий вид державних аварійно-рятувальних служб [2].

Принципи надання медичної допомоги постраждалим у системі медицини катастроф (МК) основуються на загальних положеннях про здоров'я населення та надання йому медичної допомоги [3].

Ще М. І. Пирогов у своїх працях, які були присвячені організаційним проблемам військової медицини, показав вирішальне значення організаційної діяльності лікарського складу. Він писав: “Если врач не предло(ㄱ К. В. Вовк, О. В. Сокруто, С. Я. Ніколенко жит себе главной целью, прежде всего, действовать административно, а потом уже врачебно, то он совсем растеряется, и ни голова его, ни руки не окажут помощи".

Основна частина. Цілеспрямоване вивчення дисципліни “Медицина катастроф" (екстремальної медицини) та, передусім, іï найважливішого розділу організації медичного забезпечення населення в надзвичайних ситуаціях (НС) в системі вищих медичних навчальних закладів на додипломному етапі дозволить в більш короткі терміни набути знань, які необхідні студентам для виконання складних та відповідальних обов' язків лікаря в майбутньому [4].

Основне завдання навчання - підготовити випускників допрактичного виконання функціональних обов'язків в спеціальних формуваннях охорони здоров'я, формуваннях та закладах медичної служби цивільної оборони та служби МК відповідно до профілю факультету вищих медичних навчальних закладів.

Для лікаря знання системи лікувально-евакуаційного забезпечення населення в НС є вкрай необхідним. Це пов'язано з необхідністю швидких професійних дій в таких умовах, неприпустимості безладдя та паніки з боку медичного персоналу, що може призвести до великих людських втрат через їхні непрофесійні дії [5]. 
Перші, а іноді і єдині, знання з цього напрямку лікарі отримують саме на додипломному етапі підготовки у вищих медичних навчальних закладах у системі викладання дисципліни “Медицина катастроф”.

В рамках цього предмета майбутні лікарі знайомляться з питаннями основних заходів та засобів захисту населення в НС, силами та засобами ДСМК, правовими, директивними та нормативними актами України щодо перебудови системи медичного постачання лікувальних закладів при НС, принципами лікувальноевакуаційного забезпечення в системі ДСМК, санітарно-гігієнічним та протиепідемічним забезпеченням населення в зоні НС тощо. Студенти також знайомляться із заходами щодо запобігання або зменшення ступеня ураження людей, своєчасного надання медичної допомоги потерпілим та їх лікування.

Колективом кафедри 3 метою вдосконалення навчального процесу було розроблено тестові завдання для кожної теми (по 30 завдань), ситуаційні задачі (як для одного студента, так і для групи в цілому 3 розподілом ролей - ролеві ситуаційні задачі). Згідно з вмістом задач першого рівня складності залежно від конкретної НС студент повинен визначити тип та важкість ушкодження, зробити сортування постраждалих, послідовність евакуаційних засобів, визначити тип лікуально-профілактичного закладу, куди потрібно евакуювати потерпілого. Щодо задач другого рівня складності, то вони вмістять завдання стосовно безпосереднього надання долікарської та першої медичної допомоги в осередку НС. Задачі третього рівня складності стосуються організації

\section{Лiтература}

1. Камбалов М. Н. О необходимости совершенствования организации преподавания дисциплины "Медицина экстремальных ситуаций” при подготовке офицеров медицинской службы запаса / М. Н. Камбалов, С. А. Анашкина // Военная медицина. - 2008. - № 1. - С. 15-16.

2. Про створення Державної служби медицини катастроф : Постанова Кабінету Міністрів України від 14 квітня 1997 p. № 343. - К., 1997. - 3 c.

3. Медицина катастроф / [Грідасов В. І., Ковальов В. М., роботи як бригад, що перші прибули до осередку НС, так і бригад першої та другої черги швидкої медичної допомоги. Задачі четвертого рівня стосуються алгоритму надання медичної допомоги постраждалим в НС.

Висновки. Отримання вищої освіти припускає підготовку фахівця, який надалі може зайняти керівну посаду організатора підрозділу, у підпорядкуванні якого будуть знаходитися люди. Стосовно студентівмедиків це є можливість стати в подальшому завідувачем відділення, заступником головного лікаря або головним лікарем лікувального закладу, у веденні якого знаходяться не тільки медичні працівники, але й хворі, які лікуються в цьому закладі. Рішучість дії керівника, самовладання і впевненість у складній обстановці НС мирного або воєнного часу допомагають підлеглим у цих умовах виявляти витримку і мужність, зміцнюють почуття обов'язку.

Отже, знання планування та використання існуючих сил та засобів закладів охорони здоров'я незалежно від їх форм власності дозволить майбутнім лікарям не тільки самим правильно діяти в надзвичайній обстановці, але й впевнено керувати діями підлеглих.

Таким чином, вивчення дисципліни "Медицина катастроф” у системі вищої медичної освіти сприяє підготовці кваліфікованих фахівців-лікарів, які здатні виконувати свої професійні обов' язки не тільки в умовах мирного часу, але й в НС, що дозволить зменшити людські втрати та запобігти розвитку санітарної катастрофи.

Катрич М. В. та ін.]. - Х. : НфаУ, 2002. - 294 с.

4. Особенности преподавания медицины катастроф в медицинском вузе / С. В. Флюрик, В. М. Ивашин, В. Н. Корабач, А. Н. Глебов // Совершенствование системы подготовки военных кадров на военном факультете : матер. II военно-научной конф. - Гродно, 2008. - С. 113-117.

5. Якімов Ю. М. Медицина катастроф : навчально-методичний посібник / Якімов Ю. М., Савченко В. М., Радченко Ю. В. -Х. : ХНУ імені В. Н. Каразіна, 2006. - 156 с. 